\title{
Sprawozdanie z prac w Fundacji Archivum Helveto-Polonicum we Fryburgu w Szwajcarii w 2018 r.
}

Fundacja Archivum Helveto-Polonicum (dalej: AHP) oficjalnie założona została w Szwajcarii 27 czerwca 1997 r., ale jej początków należy szukać w działalności kolekcjonerskiej Ludwiki i Jacka Sygnarskich prowadzonej jeszcze w Polsce w latach 70. i 80. XXw.

Zbiory Fundacji podzielono na trzy główne działy: Archiwum, Biblioteka i Ekspozycja stała. Zasób Archiwum obejmuje różnorodne materiały archiwalne, tj. dokumentację aktową (w przeważającej części epistolograficzną), fotograficzną, audiowizualną (np. w postaci kaset magnetofonowych i wideo), kartograficzną, ikonograficzną, druki ulotne itp.). W dziale Biblioteka przechowywane są wydawnictwa emigracyjne, polonika, tzw. wydawnictwa jerozolimskie. Zgromadzono także bogaty zbiór bibuły, czyli wydawanych w drugim obiegu druków, ulotek i wszelkich publikacji związanych z działalnością opozycji politycznej. Ekspozycję stałą tworzą natomiast obiekty o charakterze muzealnym, a więc: rysunki, szkice, obrazy, rzeźby i różnego rodzaju przedmioty pamiątkowe. Jest to część spuścizn i archiwów prywatnych przekazanych do Fundacji. AHP gromadzi wszelkie pozostałości po polskich żołnierzach 2 Dywizji Strzelców Pieszych internowanych w czasie II wojny światowej na terenie Szwajcarii (np. mundury, hełmy, ołtarze polowe, broń, tablice pamiątkowe). W Fundacji podziwiać można także prace Jacka Stryjeńskiego, m.in. kartony projektów witraży znajdujących się w genewskich kościołach św. Teresy i św. Franciszka, makietę żelaznej kurtyny dla Teatru Wielkiego w Genewie czy teatr marionetek ${ }^{1}$.

Fundacja od blisko dziesięciu lat korzysta z doraźnego wsparcia Naczelnej Dyrekcji Archiwów Państwowych (dalej: NDAP) w zakresie prac porządkowo-ewidencyjnych i digitalizacji. W ramach pomocy dla instytucji polonijnych udzielanej przez NDAP od 17 września 2018 r. do 9 listopada 2018 r. wspomagałyśmy Fundację w pracach porządkowo-ewidencyjnych oraz $\mathrm{w}$ procesie digitalizacji materiałów archiwalnych. Rok ten był szczególny dla Fundacji nie tylko ze względu na wyjątkowo dużą (w stosunku do lat poprzednich) pomoc ze strony polskiej służby archiwalnej, ale także z powodu wdrożenia Zintegrowanego Systemu Informacji Archiwalnej (dalej: ZoSIA). Dzięki temu w systemie znalazły się opisy wszystkich zespołów archiwalnych aktualnie wydzielonych w AHP oraz część inwentarzy.

W czasie pobytu, zgodnie ze wskazówkami Jacka Sygnarskiego - prezesa Fundacji, pracami porządkowo-ewidencyjnymi objęłyśmy korespondencję Marii i Zygmunta Estreicherów z lat 1939-1956 oraz całą przekazaną do AHP Spuściznę Mieczysława Habichta z lat ok. 1931-1982 [1983]. Wszelkie czynności konsultowane były z J. Sygnarskim i wyko-

${ }^{1}$ Informacje o Fundacji i jej zasobie por. Okruchy naszej historii. Fundacja „Archivum Helveto-Polonicum”, red. Beata Kułak, Jolanta Leśniewska, Jacek Sygnarski, Fryburg 2017. 
nywane zgodnie z poczynionymi ustaleniami oraz z poszanowaniem przyjętego w Fundacji sposobu porządkowania, ewidencjonowania, opisywania, a także digitalizacji materiałów archiwalnych. Sposób ten różni się od metodyki opracowywania materiałów archiwalnych stosowanej w archiwach państwowych, stąd konieczność zaznaczenia tych rozbieżności.

Materiały archiwalne objęte naszymi pracami zostały zewidencjonowane w ZoSIA, dzięki czemu inwentarze, a częściowo także kopie cyfrowe, dostępne będą dla użytkowników online za pośrednictwem portalu www.szukajwarchiwach.pl (ostateczną decyzję o publikacji materiałów archiwalnych podejmuje J. Sygnarski). Dla zewidencjonowanej dokumentacji w systemie przygotowane zostały również indeksy osobowe, rzeczowe i geograficzne jako dodatkowe pomoce archiwalne o charakterze informacyjnym. Uporządkowane przez nas archiwalia zostały też zdigitalizowane.

Porządkowanie materiałów archiwalnych odbywało się z poszanowaniem zasad przyjętych dla całego zasobu AHP. Korespondencję Marii i Zygmunta Estreicherów ułożono chronologicznie i opatrzono, w większości, znakami własnościowymi i sygnaturami dokumentów. Do tak uporządkowanych i osygnowanych listów dołączałyśmy, uwzględniając datację, korespondencję jeszcze bez naniesionych znaków własnościowych i sygnatur, która została wydzielona pierwotnie do odrębnych segregatorów, wyłącznie ze względu na swój mniejszy format. Zgodnie z wytycznymi J. Sygnarskiego otrzymywała ona sygnaturę dokumentu poprzedzającego, $\mathrm{z}$ dodaniem ostatnich liter alfabetu w formie majuskulnej. Korespondencję, przechowywaną pierwotnie w koszulkach wykonanych z tworzywa sztucznego, przepakowano do okładzin z papieru bezkwasowego (po ok. 10 listów w jednej), które dodatkowo zabezpieczono teczkami i pudłami z tektury litej bezkwasowej. Jednostki archiwalne otrzymały tytuły oraz zostały zewidencjowane pierwotnie w pliku MS Excel. Plik ten zawiera również indeksy osobowe, rzeczowe i geograficzne (dopiero po otrzymaniu kont w ZoSIA ewidencja i indeksy zaimportowano do systemu). W indeksie osobowym i geograficznym odnotowano wszystkie odczytane nazwiska i nazwy miejscowości.

Podczas prac nad Spuścizną Mieczysława de Habichta wytypowano następujące serie: Dokumenty osobiste DO (AHP HABI-DO), Dokumenty DK (AHP HABI-DK), Korespondencja KO (AHP HABI-KO), Zaproszenia ZA (AHP HABI-ZA), Druki DR (AHP HABI-DR), Fotografie FO (AHP HABI-FO), Rękopis MA (AHP HABI-MA). Pojedyncze dokumenty, po uporządkowaniu chronologicznym lub alfabetycznym (taki układ przyjęto w odniesieniu do niedatowanych oznaczeniem roku zaproszeń), zostały zabezpieczone w sposób podobny jak korespondencja M. i Z. Estreicherów, a więc przepakowane w okładziny z papieru bezkwasowego, a następnie w teczki i pudła $\mathrm{z}$ tektury litej bezkwasowej. Zarówno na okładziny, teczki, jak i pudła naniesiono sygnatury tworzone zgodnie z przyjętymi w AHP zasadami. Sposób sygnowania obowiązujący w AHP obejmuje skróty literowe: nazwy Fundacji (AHP), nazwy zespołu (HABI), nazwy serii (KO). W ramach serii każda kartka była numerowana odrębnie, zaczynając od numeru jeden. Kolejne egzemplarze wizytówek lub pustych druków, na prośbę J. Sygnarskiego, pozostawiano w teczkach. Sygnowane były one tymi samymi sygnaturami co ich pierwsze egzemplarze i nie podlegały digitalizacji. Fotografie zostały odklejone z samoprzylepnych kart albumu przekładanego folią, a następnie każdą z nich zapakowano w odrębną okładzinę z papieru bezkwasowego dostosowaną do jej rozmiarów. Tak przepakowaną dokumentację również zabezpieczono teczkami i pudłami z tektury litej bezkwasowej. Przed 
rozpoczęciem tych prac, na prośbę J. Sygnarskiego, wykonano kserokopie poszczególnych kart albumu mające odzwierciedlać pierwotny jego układ.

W ten sposób uzyskano łącznie dla obu zespołów 54 j.a. złożone w dziesięciu pudłach z tektury litej bezkwasowej (z istniejących do tej pory 59 segregatorów i albumu ze zdjęciami). Nasze działania poprawiły stan przechowywania dokumentacji oraz przyczyniły się do zmniejszenia jej metrażu, co jest istotne ze względu na trudną sytuację lokalową Fundacji.

Dokumentacja aktowa, fotograficzna oraz druki ulotne składające się na Spuściznę Mieczysława de Habichta (zespół 716/2/10) oraz część korespondencji M. i Z. Estreicherów (zespół 716/2/5) zostały zeskanowane w rozdzielczości 600 dpi, w formacie TIFF, przy czym nazwa pliku odpowiada sygnaturze dokumentu. W wypadku zapisanych odwrotnych stron lub kolejnych kartek tego samego dokumentu - dokumenty sygnowane były poprzez dodanie w sygnaturze, po numerze dokumentu, kolejnej litery alfabetu (,a, b, c” itd.). Zaznaczyć należy, że każdy skan - na prośbę J. Sygnarskiego i zgodnie z przyjętymi zasadami - opisywany był dodatkowymi informacjami. Składały się na nie następujące elementy: słowo kluczowe, tytuł (w przypadku korespondencji w tytule ujmowana była także miejscowość i data listu), autorzy, opis obiektu, np. list, zaproszenie, fotografia wraz z podaniem wysokości i szerokości obiektu ${ }^{2}$. Przed przystąpieniem do prac digitalizacyjnych, na prośbę J. Sygnarskiego, przeprowadzono aktualizację oprogramowania skanerów na wszystkich komputerach Fundacji oraz zainstalowano oprogramowanie skanera na jednym z nich. Były to działania konieczne, umożliwiające rozpoczęcie procesu digitalizacji. Wszystkie kopie cyfrowe zostały zapisane w kilku lokalizacjach - na dyskach komputerów lokalnych w siedzibie Fundacji i dyskach zewnętrznych.

W trakcie pobytu uporządkowałyśmy i zewidencjonowałyśmy 54 j.a., sporządziłyśmy 856 haseł w indeksach osobowych, rzeczowych i geograficznych oraz wykonałyśmy 4158 szczegółowo opisanych skanów, co stanowi 86,70 GB.

Podsumowując, postulujemy dalsze udzielanie wsparcia Fundacji ze strony NDAP. Bogaty zasób archiwalny wart jest popularyzacji w Polsce. Unikatowe zbiory, np. wydawnictwa drugiego obiegu, powinny zostać zdigitalizowane i udostępnione szerokiemu gronu odbiorców. Wsparcie NDAP powinno dotyczyć także płaszczyzny informatycznej, nie tylko w odniesieniu do wdrażania systemu ZoSIA, ale i technicznego zabezpieczania, konfiguracji i aktualizacji sprzętu teleinformatycznego.

Agnieszka Filipek, Grażyna Spyrka Archiwum Narodowe w Krakowie

${ }^{2}$ Przykłady opisu kilku skanów: AHP HABI-KO_002a Habicht; Korespondencja - Mieczysław Habicht - Bronisława Rychter-Janowska - Kraków, 10.04.1951; Bronisława Rychter-Janowska; List 21x15, skan AHP HABI-ZA_308 Habicht; Mieczysław Habicht - zaproszenie - Georges Galichen - 11.01.1977; zaproszenie 13x17, AHP HABI-MA_011b Habicht; List Kazimierza Habichta do Mieczysława Habichta; Kazimierz Habicht; List $15 \times 18$. 